\title{
Influence of partial starvation and of acute scurvy on the free amino acids in blood plasma and muscle in the guinea-pig
}

\author{
BY F. SCHØNHEYDER AND J. LYNGBYE \\ Department of Biochemistry, University of Arhus, Denmark \\ (Received I May 1961-Revised I 2 fune 1961)
}

Various investigators have reported changes in the concentration of the free amino acids in blood plasma and tissues of guinea-pigs in acute vitamin $\mathrm{C}$ deficiency. Christensen \& Lynch (1948) found in guinea-pigs deficient in ascorbic acid a large decrease in the glycine and glutamine contents of skeletal muscle and in the glutamine content of the liver. Levels of amino acids other than glycine and glutamine, determined as non-glutamine $\alpha$-amino nitrogen, tended to be elevated in the liver, in plasma and especially in muscle. Guinea-pigs restricted in food intake did not show significant changes in glycine and glutamine distribution. Ginter (1957) studied the free amino acids of the skeletal muscle of guinea-pigs deprived of ascorbic acid. He found an increase in the glutamic acid level and the valine-methionine and leucine fractions, and a reduction in the level of glutamine and aspartic acid. By comparison of the amino acid content of blood plasma in ascorbic acid-deficient and normal guinea-pigs, Rangneker \& Dugal (1958) found that in the former arginine, threonine, hydroxyproline and cystine were absent and the levels of leucine, valine, alanine, glutamic acid, serine and glycine were lower than in normal animals. On the other hand, the levels of phenylalanine, lysine and histidine were higher. The results of Ginter (1957) and Rangneker \& Dugal ( $195^{8}$ ) were obtained by the technique of paper chromatography.

The development of the Moore \& Stein (1954) technique for amino acid analysis gave us the opportunity to carry out a systematic study of the free amino acids of blood plasma and muscle tissue in the guinea-pig and to test former observations. Our studies indicated that the majority of the changes in the concentration of free amino acids in the tissues of animals with experimental scurvy are not specific for ascorbic acid deficiency, the findings not deviating essentially from those observed with guinea-pigs subjected to partial starvation.

\section{EXPERIMENTAL}

Animals, diet and collection of samples

Young guinea-pigs of both sexes, weighing about $25 \circ \mathrm{g}$ each, were put on a diet which was a slight modification of that recommended by Sherman, LaMer \& Campbell (1922). The composition of the basal diet is given in Table 1 . In addition, the animals were given hay, heated to $120^{\circ}$ for $5 \mathrm{~h}$ before use, and water, both ad lib. Each animal received daily by mouth $5 \mathrm{mg}$ ascorbic acid. When $\mathrm{r} 6$ days had passed the animals, now weighing about $300 \mathrm{~g}$, were divided into three groups. They were kept in indi- 


\section{Table 1. Percentage composition of basal diet}

$\begin{array}{lrll}\text { Whole oats* } & 38 \cdot 0 & \text { Yeast (dry) } & 2 \cdot 0 \\ \text { Wheat bran* } & 17 \cdot 5 & \text { Calcium carbonate } & 0 \cdot 5 \\ \text { Skim-milk powder* } & 29^{*} 4 & \text { Potassium phosphate }\left(\mathrm{KH}_{2} \mathrm{PO}_{4}\right) & 0 \cdot 5 \\ \text { Margarine } & 9 \cdot 8 & \text { Salt mixturet } & 2 \cdot 4 \\ & & \text { Vitamins } \downarrow & \end{array}$

* Kept at $110^{\circ}$ for $15 \mathrm{~h}$ before use.

$\uparrow$ Hansard, Comar \& Plumlee (1951).

I Supplements of fat-soluble vitamins were given orally to the animals once weekly: $\alpha$-tocopheryl acetate, $5 \%(\mathrm{w} / \mathrm{v})$ in arachis oil, four drops; 2 -methyl-1,4-naphthaquinone, $0.25 \%(\mathrm{w} / \mathrm{v})$ in $0.001 \mathrm{~N}-$ $\mathrm{HCl}$, two drops; cod-liver oil, two drops.

The components, except the vitamins, were kneaded together with water and baked into buns (baking time $15 \mathrm{~min}$ ).

vidual cages. Group I (positive control group), twelve animals, continued on the diet given ad lib., with the additional ascorbic acid. Group 3 (scorbutic group), sixteen animals, was given the diet $a d$ lib., without the ascorbic acid. Group 2, six animals, had the diet with the ascorbic acid, but restricted so that the weight curves of these animals followed the weight curves of the animals in group 3 as closely as possible. The restriction in the quantities of the basal diet and of the hay was begun after 16 days when the group 3 animals began to lose weight, and during the last 2 days of the experiment the group 2 animals were given ascorbic acid and unrestricted water only. In this way it was possible to bring their weight nearly to that of the scorbutic animals. When the animals in group 3 began to lose weight, their activity lessened and their joints became tender. After another 12 days the animals, now eating very little food, were killed after being anaesthetized with Nembutal (Abbott Laboratories Ltd, London). Blood amounting to $8-15 \mathrm{ml}$ was taken by heart puncture into heparinized syringes. The animals in groups $\mathbf{I}$ and 2 were killed at the same time. At autopsy signs of pronounced scurvy (bleeding in and around the joints, bleeding in the breast musculature and fragility of bones) were noted in all the animals in group 3. The animals in groups $\mathrm{I}$ and 2 were found to be normal in this respect. In order to obtain sufficient material for the investigation, all the analyses were done on pooled muscle tissue or blood plasma from two animals in the respective groups. The muscle tissue was taken from the extremities and cooled to $0^{\circ}$ immediately after removal.

\section{Analysis of samples}

Amino acids. These were determined by the method of Moore \& Stein (1954) which involves the use of ion-exchange resins for elution chromatography. Plasma was deproteinized with picric acid and this acid removed as described by Stein $\&$ Moore (1954). Muscle tissue weighing $2 \mathrm{~g}$, freed from visible fat, was ground with sand. This tissue was deproteinized with $30 \mathrm{ml} \mathrm{I} \%(\mathrm{w} / \mathrm{v})$ picric acid, and then the picric acid extract was treated in the same way as the extract of plasma. The chromatographically separated amino acids were identified by paper chromatography of desalted fractions in two solvent systems, with glutamine in only one system. The valine peak contained unidentified impurities and the results for this acid are therefore approxi- 
mate. No attempt has been made to determine tryptophan and cystine. The recovery in experiments on amino acid mixtures of known composition was found to be within $5 \%$ of the expected value except for methionine and arginine for which the recoveries were $95 \pm 2 \%$ and $96 \pm 2 \%$, respectively. In the calculation of the amounts of methionine and arginine the values found were divided by 0.95 and 0.96 , respectively.

Carnosine and anserine were determined by the ion-exchange method described by Davey (1957). The colour values (with ninhydrin reagent) of carnosine and anserine, dissolved in the buffer in which they emerge from the column, were determined (on I $\mathrm{ml}$ ) on a molar basis relative to leucine and were found to be 0.80 and 0.67 , respectively. In the calculation of the amounts of anserine the value found was divided by 0.93 to correct for losses during chromatography.

Creatine. The procedure described by Eggleton, Elsden \& Gough (1943) was used.

Inorganic electrolytes. Chloride was determined by the method of Brun (1949) in plasma and by the method of Sunderman \& Williams (1933) in muscle tissue. Sodium and potassium were determined by flame photometry, in plasma after electrolysis and in tissues after ashing (Ørskov, 1952-3).

Dry matter. Weighed samples were dried at $80^{\circ}$ for $24 \mathrm{~h}$ and then to constant weight in a desiccator over $\mathrm{P}_{2} \mathrm{O}_{5}$.

\section{RESULTS}

Fig. I shows the mean weights of the animals from the time they were divided into three groups. The rate of weight gain was roughly the same in the groups for the first I 6 days, then the weight decreased in the animals not given ascorbic acid.

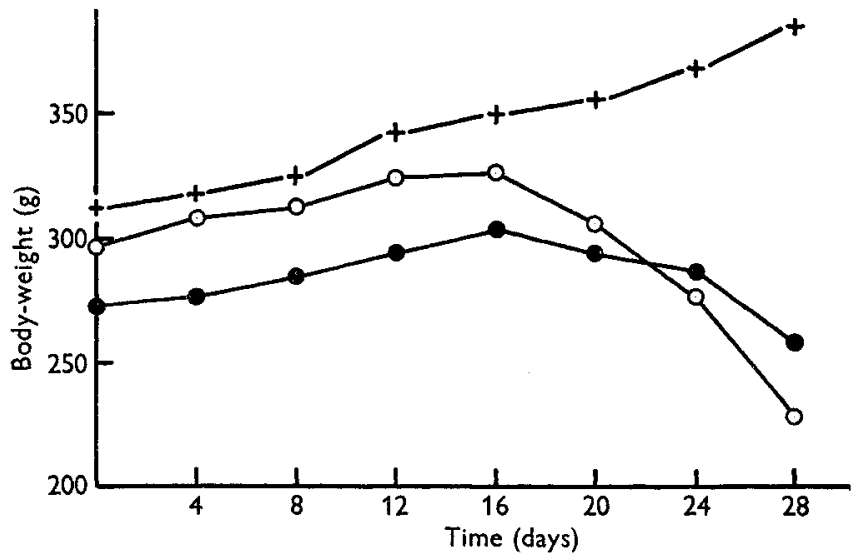

Fig. I. Mean weight curves of groups of guinea-pigs. +-+ , positive control group (twelve animals); $\mathrm{O}-\mathrm{O}$, scorbutic group (sixteen animals); -- control group on restricted diet with ascorbic acid (six animals).

The results of the assays on blood plasma and muscle tissue are shown in Tables 2 and 3. It will be seen that in the guinea-pig the glycine content is remarkably high in relation to that of the other free amino acids, especially in the plasma. In Table 4 values for the total free amino nitrogen and free glycine nitrogen in guinea-pig plasma and muscle are compared with similar measurements found in previous investigations on other species. 
Table 2. Mean values and standard deviations for concentrations of free amino acids, taurine and inorganic electrolytes in blood plasma of normal (I), partially starved (2) and scorbutic (3) guinea-pigs

\begin{tabular}{|c|c|c|c|c|c|c|}
\hline \multirow[t]{2}{*}{ (2) } & \multirow{2}{*}{$\begin{array}{l}\text { Group I } \\
\text { ( } \mu \text { moles/ } \\
\text { rooo ml) }\end{array}$} & \multirow{2}{*}{$\begin{array}{l}\text { Group 2 } \\
\text { ( } \mu \text { moles/ } \\
\text { 1000 ml) }\end{array}$} & \multirow{2}{*}{$\begin{array}{c}\text { Group } 3 \\
\text { ( } \mu \text { moles/ } \\
\text { rooo ml) }\end{array}$} & \multicolumn{3}{|c|}{$\begin{array}{c}\text { Level of significance, } P \text {, of } \\
\text { group differences }\end{array}$} \\
\hline & & & & $(2)-(1)$ & $(3)-(I)$ & $(3)-(2)$ \\
\hline Aspartic acid & I9土7 & $17 \pm 5$ & $19 \pm 6$ & 一 & - & - \\
\hline Threonine & $70 \pm 12$ & $131 \pm 24$ & $102 \pm 9$ & $<0.01$ & $<0.001$ & $<0.05$ \\
\hline Serine & $148 \pm 23$ & $122 \pm 87$ & $142 \pm 62$ & - & - & - \\
\hline Glutamine & $60 \pm 26$ & $64 \pm 55$ & $49 \pm 28$ & - & 一 & - \\
\hline Proline & $82 \pm 22$ & $53 \pm 9$ & $71+22$ & - & - & - \\
\hline Glutamic acid & $198 \pm 41$ & $120 \pm 14$ & $105 \pm 47$ & $<0.05$ & $<0.02$ & - \\
\hline Glycine & $1987 \pm 238$ & $1088 \pm 242$ & $834 \pm 526$ & $<0.01$ & $<0.01$ & - \\
\hline Alanine & $198 \pm 97$ & $210 \pm 27$ & $204 \pm 57$ & - & - & - \\
\hline Valine & $190 \pm 25$ & $242+40$ & $248 \pm 5^{1}$ & $=0.05$ & $=0.05$ & - \\
\hline Methionine & $16 \pm 4$ & $26 \pm 3$ & $24 \pm 6$ & $<0.02$ & $<0.05$ & - \\
\hline Isoleucine & $65 \pm \pm 3$ & $76 \pm 19$ & $8 r \pm 2 r$ & - & - & - \\
\hline Leucine & $88 \pm 18$ & $117 \pm 24$ & $120 \pm 33$ & - & - & - \\
\hline Tyrosine & $29 \pm 8$ & $39 \pm 4$ & $48 \pm 13$ & - & $<0.02$ & - \\
\hline Phenylalanine & $47 \pm 10$ & $49 \pm 2$ & $67 \pm 6$ & - & $<0.01$ & $<0.01$ \\
\hline Ornithine & $48 \pm$ II & $5^{1 \pm 8}$ & $73 \pm 26$ & - & - & - \\
\hline Lysine & $64 \pm 12$ & $147 \pm 15$ & $123 \pm 22$ & $<0.001$ & $<0.001$ & - \\
\hline Histidine & $42 \pm 10$ & $52 \pm 8$ & $45 \pm I_{4}$ & - & - & - \\
\hline Arginine & $23 \pm I I$ & $67 \pm 10$ & $66 \pm 8$ & $<0.01$ & $<0.001$ & - \\
\hline Taurine & $25 \pm 7$ & $83 \pm 14$ & $130 \pm 57$ & $<0.001$ & $<0.01$ & 一 \\
\hline Chloride & $(100 \pm 2 \cdot 9) 10^{3}$ & $(\operatorname{rox} \pm x \cdot 6) 10^{3}$ & $(98 \pm 4 \cdot 4) 10^{3}$ & - & - & - \\
\hline Sodium & $(137 \pm 3.6) 10^{3}$ & $(132 \pm 3.2) 10^{3}$ & $(136 \pm 3.6) 10^{3}$ & - & - & 一 \\
\hline Potassium & $(5.5 \pm 0.4) 10^{3}$ & $(5.5 \pm 0.2) 10^{3}$ & $(5 \cdot 6 \pm 1 \cdot 0) 10^{3}$ & - & - & - \\
\hline
\end{tabular}

Each determination was done on blood plasma from two animals. The means for groups $\mathbf{1}, 2$ and 3 are based on five, three and six determinations, respectively. The means for taurine and glutamic acid in group I are based on four determinations only. The chloride, sodium and potassium means for group I are based on six determinations and those for group 3 on eight.

After food restriction for Io days and starvation for 2 days (group 2) values for seven of the amino acids and taurine in plasma showed significant differences from those found for the normal controls. The concentrations of glycine and glutamic acid were decreased, whereas the concentrations of threonine, valine, methionine, lysine, arginine and taurine were enhanced. The plasma amino acid values for the scorbutic group (group 3) showed the same relations to those for normal controls as did the values for the starved animals. In addition, the concentrations of tyrosine and phenylalanine were enhanced relatively to those in normal animals. Comparison of the results for scorbutic and starved animals showed small differences. The elevation of the threonine content was less pronounced and of that of phenylalanine more pronounced in scorbutic than in starved animals. Among the electrolytes examined no differences between the groups were demonstrated.

As expected, we found the concentrations of the free amino acids considerably higher in muscle tissue than in plasma, and the relative amounts of the individual amino acids were quite different. Carnosine and anserine were seen only in small amounts but, as in most animals, anserine dominated (Zapp \& Wilson, 1938). Restricted feeding caused significant changes in taurine and in twelve of the amino acids examined in muscle. Thus, the concentrations of proline, glutamic acid and glycine 
Table 3. Mean values and standard deviations for concentration of free amino acids, related substances, and inorganic electrolytes in muscle tissue of normal (I), partially starved (2) and scorbutic (3) guinea-pigs

\begin{tabular}{|c|c|c|c|c|c|c|}
\hline & \multirow{2}{*}{$\begin{array}{l}\text { Group I } \\
\text { (m-moles/ } \\
\text { 1000 g) }\end{array}$} & \multirow{2}{*}{$\begin{array}{c}\text { Group 2 } \\
\text { (m-moles } \\
\text { 1000 g) }\end{array}$} & \multirow{2}{*}{$\begin{array}{l}\text { Group 3 } \\
\text { (m-moles/ } \\
1000 \mathrm{~g})\end{array}$} & \multicolumn{3}{|c|}{$\begin{array}{l}\text { Level of significance, } P \text {, of } \\
\text { group differences }\end{array}$} \\
\hline & & & & $(2)-(1)$ & $(3)-(1)$ & $(3)-(2)$ \\
\hline Aspartic acid & $0.14 \pm 0.06$ & $0.07 \pm 0.02$ & $0.24 \pm 0.04$ & - & $<0.01$ & $<0.001$ \\
\hline Threonine & $0.22 \pm 0.05$ & $0.38 \pm 0.05$ & $0.45 \pm 0.09$ & $<0.01$ & $<0.001$ & - \\
\hline Serine & $0.77 \pm 0.11$ & $0.58 \pm 0.12$ & $0.70 \pm 0.11$ & - & - & - \\
\hline Glutamine & $0.54 \pm 0.23$ & $0.32 \pm 0.04$ & $0.28 \pm 0.09$ & - & $<0.05$ & - \\
\hline Proline & $0.65 \pm 0.14$ & $0.37 \pm 0.02$ & $0.44 \pm 0.09$ & $<0.02$ & $<0.02$ & - \\
\hline Glutamic acid & $0.99 \pm 0.23$ & $0.43 \pm 0.09$ & $0.92 \pm 0.40$ & $<0.01$ & - & - \\
\hline Glycine & $10.64 \pm 0.66$ & $4.24 \pm 0.90$ & $3 \cdot 34 \pm 2 \cdot 17$ & $<0.001$ & $<0.001$ & - \\
\hline Alanine & $r \cdot 65 \pm 0.28$ & $2 \cdot 38 \pm 0.30$ & $2 \cdot 44 \pm 0.43$ & $<0.02$ & $<0.01$ & - \\
\hline Valine & $0.18 \pm 0.04$ & $0.33 \pm 0.06$ & $0.45 \pm 0.10$ & $<0.01$ & $<0.001$ & - \\
\hline Methionine & $0.06 \pm 0.03$ & $0.08 \pm 0.01$ & $0.10 \pm 0.03$ & - & - & - \\
\hline Isoleucine & $0.12 \pm 0.02$ & $0.20 \pm 0.03$ & $0.26 \pm 0.05$ & $<0.01$ & $<0.001$ & - \\
\hline Leucine & $0.15 \pm 0.04$ & $0.26 \pm 0.04$ & $0.36 \pm 0.05$ & $<0.01$ & $<0.001$ & $<0.05$ \\
\hline Tyrosine & $0.06 \pm 0.01$ & $0.10 \pm 0.02$ & $0.17 \pm 0.03$ & $<0.01$ & $<0.001$ & $<0.01$ \\
\hline Phenylalanine & $0.09 \pm 0.04$ & $0.13 \pm 0.02$ & $0.21 \pm 0.03$ & - & $<0.001$ & $<0.01$ \\
\hline Ornithine & $0.16 \pm 0.05$ & $0.15 \pm 0.06$ & $0.18 \pm 0.06$ & 一 & - & - \\
\hline Lysine & $0.16 \pm 0.06$ & $0.5^{8} \pm 0.05$ & $0.54 \pm 0.12$ & $<0.001$ & $<0.001$ & 一 \\
\hline Histidine & $0.10 \pm 0.01$ & $0.18 \pm 0.01$ & $0.18 \pm 0.02$ & $<0.001$ & $<0.001$ & $\ldots$ \\
\hline Arginine & $0.09 \pm 0.05$ & $0.20 \pm 0.03$ & $0.26 \pm 0.05$ & $<0.02$ & $<0.001$ & - \\
\hline Taurine & $7.55 \pm 1.07$ & $10.97 \pm 1.37$ & $12 \cdot 06 \pm 2 \cdot 33$ & $<0.01$ & $<0.01$ & - \\
\hline Carnosine & $0.68 \pm 0.12$ & $0.78 \pm 0.09$ & $0.67 \pm 0.12$ & - & - & - \\
\hline Anserine & $2.07 \pm 0.24$ & $2 \cdot 32 \pm 0.08$ & $3.15 \pm 0.84$ & - & $<0.05$ & - \\
\hline Creatine & $35 \cdot 1+2.7$ & $40.0 \pm 3.2$ & $32 \cdot 1 \pm r \cdot 3$ & - & $<0.05$ & $<0.001$ \\
\hline Chloride & $16.8 \pm I \cdot 3$ & $17 \cdot 3 \pm 0.8$ & $25.7 \pm 2.9$ & 一 & $<0.001$ & $<0.01$ \\
\hline Sodium & $23.7 \pm 1.7$ & $25.4 \pm x \cdot 6$ & $37 \cdot 1 \pm 4 \cdot 6$ & - & $<0.001$ & $<0.01$ \\
\hline Potassium & $86.1 \pm 15.4$ & $97 \cdot 3 \pm 1.9$ & $79.4 \pm 9.4$ & - & - & $<0.02$ \\
\hline Dry matter* & $23 \cdot 7 \pm 1 \cdot 4$ & $23.3 \pm 1.0$ & $23.8 \pm 1.7$ & - & - & - \\
\hline
\end{tabular}

* Expressed as percentage of wet weight.

Each determination was done on muscle tissue from two animals. The means for groups I, 2 and 3 originate from five, three and six determinations, respectively. The chloride, sodium and potassium means for group $\mathrm{I}$ were all obtained from six determinations and those for group 3 from eight.

Table 4. Total free $\alpha$-amino nitrogen and free glycine nitrogen in blood plasma and muscle of different species

\begin{tabular}{|c|c|c|c|c|c|}
\hline & & \multicolumn{2}{|c|}{ Plasma $(\mathrm{mg} / \mathrm{r} 00 \mathrm{ml})$} & \multicolumn{2}{|c|}{ Muscle (mg/roo g) } \\
\hline eference & Species & $\begin{array}{c}\text { Total } \\
\text { free } \\
\alpha \text {-amino } \\
\text { nitrogen }\end{array}$ & $\begin{array}{c}\text { Free } \\
\text { glycine } \\
\text { nitrogen }\end{array}$ & $\begin{array}{c}\text { Total } \\
\text { free } \\
\alpha \text {-amino } \\
\text { nitrogen }\end{array}$ & $\begin{array}{c}\text { Free } \\
\text { glycine } \\
\text { nitrogen }\end{array}$ \\
\hline (1954) & Man & $4 \cdot 0$ & $0.29 \pm 0.03$ & - & - \\
\hline \& Stein (1954) & $\begin{array}{l}\text { Cat } \\
\text { Rat }\end{array}$ & $\begin{array}{l}5-7 * \\
6 \cdot 2-7 \cdot 0\end{array}$ & $\begin{array}{l}0.43 \\
0.56+0.08\end{array}$ & $\begin{array}{l}82 \cdot 5-102 * \\
27 \cdot 5-32 \cdot 4\end{array}$ & $\begin{array}{l}1 \cdot 3 \\
3 \cdot 8 \pm 0.3\end{array}$ \\
\hline $\begin{array}{l}\text { ua \& Fuerst (I 950) } \\
\text { Lyngbye (this }\end{array}$ & $\begin{array}{l}\text { Rat } \\
\text { Guinea-pig }\end{array}$ & $5-\overline{-}$ & $2.78 \pm 0.15$ & $\begin{array}{l}49 \cdot 1 \pm 5 \cdot 2 \\
52 \cdot 5-60^{*}\end{array}$ & $\begin{array}{r}8 \cdot 0 \pm 0.8 \\
14.9 \pm 0.4\end{array}$ \\
\hline
\end{tabular}

Moore \& Stein (1954)

Tallan, Moore \& Stein (1954)

Wu (1954)

Awapara, Landua \& Fuerst (1950)

Schønheyder \& Lyngbye (this work)

When possible the values are given with their calculated standard deviations.

* These determinations were done in our laboratory by Dr C. Zimmermann-Nielsen on deproteinized materials by the method described by Russell (i 944 ). 
were decreased; those of taurine, threonine, alanine, valine, isoleucine, leucine, tyrosine, lysine, histidine and arginine were increased. The amino acid values in muscle tissue from scorbutic animals showed essentially the same deviations from those for the normal group as did those of the starved animals. In addition, a significant decrease was found in the concentration of glutamine, whereas the values for aspartic acid, phenylalanine and anserine increased. The glutamic acid content was unchanged in scurvy. Comparison of the results for ascorbic acid-deficient animals and starved animals showed only small differences. The contents of aspartic acid, leucine, tyrosine and phenylalanine were, however, all significantly higher in scorbutic than in starved animals. During starvation the creatine content was found to be insignificantly higher than in normal animals, whereas in scurvy this substance appeared in a lower concentration than in normal or in starved animals. The content of potassium seemed to follow that of creatine in its changes. The contents of chloride and sodium were unchanged in starved animals, but higher in scorbutic than in starved animals.

\section{DISCUSSION}

Apart from the authors mentioned in the introductory remarks, few have been interested in the pattern of free amino acids in the blood plasma and muscle tissue of the guinea-pig. Our investigation increases the range of information on this topic. When our results are compared with those already published, it is of special interest to note that in the blood plasma of guinea-pigs glycine constitutes a far greater part of the total amino nitrogen than in that of other animals.

Our work indicates that partial starvation in the guinea-pig causes significant changes in the concentrations of taurine and seven amino acids in plasma and of taurine and twelve amino acids in muscle tissue. Monaco \& Rubino (1958) found in skeletal muscle of starved guinea-pigs a loss of free aspartic acid, glutamic acid and alanine. The claim about the last-mentioned substance is not supported by our measurements. The most remarkable finding in our results on starved guinea-pigs was the decrease in the concentrations of glycine and glutamic acid in plasma and muscle tissue and the increase in the concentrations of the basic amino acids, lysine, arginine and histidine, in muscle and of lysine and arginine in plasma. Corresponding changes have not been demonstrated in the fasting rat. As a result of a 9-day fast Wu (1954) found an increase in the plasma concentrations of taurine, valine, methionine and leucineisoleucine, whereas those of the other amino acids determined were decreased. In rat muscle, fasting produced an increase in concentration of taurine and valine, whereas that of the other amino acids was decreased. Thompson, Schurr, Henderson \& Elvehjem (1950) also studied the influence of fasting on the free amino acids in rat muscle tissue. After 7 days of fasting an increase was observed in the content of leucine, isoleucine, methionine, phenylalanine and tryptophan. Those of proline and histidine diminished, whereas those of arginine, lysine, tyrosine and threonine were unchanged.

Our experiments showed that in acute scurvy in the guinea-pig a series of changes in the free amino acids occurs in blood plasma and muscle tissue. The majority of these 
changes may, however, be explained as a result of insufficient intake of food and consequent reduction in weight. This view is supported by the finding that similar changes occurred in the animals kept for ro days on the restricted diet but given adequate ascorbic acid and then given nothing but ascorbic acid and water for 2 days before being killed.

Of the findings of Rangneker \& Dugal (r958) for blood plasma and those of Ginter (1957) for muscle tissue, we have only been able to confirm a rise of phenylalanine concentration in plasma and of leucine in muscle tissue when the values for scorbutic animals were compared with those for partially starved control animals. Christensen \& Lynch (I948) described a marked fall in the glycine concentration in tissues from scorbutic guinea-pigs. Our partially starved control animals showed a fall in the glycine concentration in plasma and muscle tissue which was similar to those found in the group of scorbutic guinea-pigs.

Our work demonstrates very few differences between experimental scurvy and partial starvation in guinea-pigs as regards the patterns of free amino acids in plasma and muscle, both deviating in a similar manner from those of normal well-nourished animals. Therefore, the changes observed in scurvy cannot be considered as specific for ascorbic-acid deficiency. Certainly the scorbutic animals had a higher content of phenylalanine in plasma and a higher content of phenylalanine, tyrosine and leucine in muscle than the partially starved controls. However, we did not succeed in making the controls lose quite as much weight as the scorbutic animals and therefore too much importance should not be ascribed to these differences. The high concentration of tyrosine and phenylalanine in muscle tissue may support the claim that ascorbic acid is important in the metabolism of these acids (Sealock \& Silberstein, 1939; Zannoni \& La Du, 1960). Recently Malathi, Sastry \& Ganguly (1961) have described an increase in the contents of phenylalanine and tyrosine in the blood, liver and kidneys of vitamin A-deficient rats.

The changes in sodium and potassium concentrations in scorbutic animals confirm the observations of Swedin, Bramante \& Ryttinger (1956) and may indicate hyperfunction of the adrenal gland (Clayton, Hammant \& Armitage, 1957).

\section{SUMMARY}

I. The patterns of taurine and eighteen free amino acids of blood plasma and muscle tissue have been determined in twelve normal well-nourished guinea-pigs, in sixteen guinea-pigs fed on a scorbutogenic diet and in six guinea-pigs fed on a diet containing ascorbic acid but restricted in such a manner that their weight curves followed as closely as possible the weight curves of the scorbutic animals. The investigation also incorporated determinations of carnosine, anserine and creatine in muscle and determinations of chloride, sodium and potassium in blood plasma and muscle.

2. In blood plasma and muscle the concentrations of glycine and glutamic acid decreased, whereas those of taurine, threonine, valine, lysine and arginine increased, during partial starvation. In addition, the contents of methionine in blood plasma 
and of alanine, isoleucine, leucine, tyrosine and histidine in muscle increased. The proline content of muscle decreased.

3. The results for the partially starved and the scorbutic animals showed only few differences, though it was noted that in the scorbutic animals the concentrations in plasma of phenylalanine and in muscle of phenylalanine, tyrosine, leucine and aspartic acid were significantly higher than in the partially starved controls.

4. In blood plasma the concentration of the electrolytes examined did not differ between the groups. In muscle tissue the chloride and sodium values were higher and the potassium content was not significantly lower in scorbutic animals compared to fasting controls.

5. The results are discussed and related to work pertaining to the subject. It is suggested that the variations in the amino acid pattern found in the scorbutic guinea-pig are not specific for ascorbic acid deficiency, but might just as well be due to starvation.

This work was aided by a grant from F. L. Smidth and Co A/S's Jubilæumsfond.

\section{REFERENCES}

Awapara, J., Landua, A. J. \& Fuerst, R. (1950). Biochim. biophys. Acta, 5, 457.

Brun, C. (1949). Nord. Med. 42, I774.

Christensen, H. N. \& Lynch, E. L. (1948). F. biol. Chem. 172, 107.

Clayton, B. E., Hammant, J. E. \& Armitage, P. (1957). F. Endocrin. 15, 284.

Davey, C. L. (1957). Nature, Lond., 179, 209.

Eggleton, P., Elsden, S. R. \& Gough, N. (1943). Biochem. F. 37, 526.

Ginter, E. (1957). Csl. Gastroent. Výz. xx, 329.

Hansard, S. L., Comar, C. L. \& Plumlee, M. P. (1951). Proc. Soc. exp. Biol., N.Y., 78, 455.

Malathi, P., Sastry, P. S. \& Ganguly, J. (1961). Nature, Lond., r89, 660.

Monaco, P. \& Rubino, F. (1958). Boll. Soc. ital. Biol. sper. 34, I57.

Moore, S. \& Stein, W. H. (1954). F. biol. Chem. 211, 893.

Ørskov, S. L. (1952-3). Acta physiol. scand. 27, 321 .

Rangneker, P. V. \& Dugal, L. P. (1958). Canad. F. Biochem. Physiol. 36, 25.

Russell, J. A. (1944). F. biol. Chem. 156, 467.

Sealock, R. R. \& Silberstein, H. E. (1939). Science, 90, 517.

Sherman, H. C., LaMer, V. K. \& Campbell, H. C. (1922). F. Amer. chem. Soc. 44, I65.

Stein, W. H. \& Moore, S. (1954). F. biol. Chem. 2rr, 915.

Sunderman, F. W. \& Williams, P. (1933). F. biol. Chem. 102, 279.

Swedin, B., Bramante, F. \& Ryttinger, L. (1956). Acta path. microbiol. scand. 39, 252.

Tallan, H. H., Moore, S. \& Stein, W. H. (1954). F. biol. Chem. $211,927$.

Thompson, H. T., Schurr, P. E., Henderson, L. M. \& Elvehjem, C. A. (1950). F. biol. Chem. r82, 47

Wu, C. (1954). F. biol. Chem. 207, 775.

Zannoni, V. G. \& La Du, B. N. (1960). 7. biol. Chem. 235, 165.

Zapp, J. A. Jr. \& Wilson, D. W. (1938). J. biol. Chem. 126, 9. 